\title{
Yun-han Chu, Larry Diamond, Andrew J. Nathan, and Doh Chul Shin, eds., How East Asians View Democracy.
}

Jean-Pierre Cabestan

\section{OpenEdition}

\section{Journals}

Édition électronique

URL : http://journals.openedition.org/chinaperspectives/4870

DOI : 10.4000/chinaperspectives. 4870

ISSN : 1996-4617

Éditeur

Centre d'étude français sur la Chine contemporaine

\section{Édition imprimée}

Date de publication : 1 septembre 2009

ISSN : 2070-3449

\section{Référence électronique}

Jean-Pierre Cabestan, «Yun-han Chu, Larry Diamond, Andrew J. Nathan, and Doh Chul Shin, eds., How East Asians View Democracy. », China Perspectives [En ligne], 2009/3 | 2009, mis en ligne le 16 octobre 2009, consulté le 24 septembre 2020. URL : http://journals.openedition.org/chinaperspectives/4870 DOI : https://doi.org/10.4000/chinaperspectives.4870

Ce document a été généré automatiquement le 24 septembre 2020

(c) All rights reserved 


\section{Yun-han Chu, Larry Diamond, Andrew J. Nathan, and Doh Chul Shin, eds., How East Asians View Democracy.}

Jean-Pierre Cabestan

1 Here is a valuable but also complex book. In fact, the reply to the question posed in the title cannot be taken for granted. The good news is that democracy is now well accepted in East Asia, and it is no longer possible to argue that there is any cultural allergy to this concept or this project. The bad news is that the political culture that underlies democracy is still fragile and vague in East Asia, allowing the Chinese authorities, for example, to enjoy the apparent support of the majority of their population in maintaining and consolidating a system that is "democratic" in name only.

2 The first comparative study of its type on East Asia, this volume is based on opinion polls conducted between June 2001 and February 2003 in six democracies (South Korea, Japan, Mongolia, the Philippines, Taiwan, and Thailand), one semi-democracy (Hong Kong), and one authoritarian country (China). The same questions were posed to significant representative samples, including in China, with only a few exceptions.

3 The results of these surveys are impressive. All of the societies studied regard democracy in a positive light. In a great majority of cases, democracy is not associated with chaos, corruption, violence, or inefficiency, but rather with fundamental freedoms and rights, with free elections and representative institutions, and with the concepts of social justice, good governance, welfare, and "government by the people and for the people." It is also interesting to note that in these societies democracy is generally not linked to the market economy or private property, in contrast, for example, to post-1989 Eastern Europe; it is rather understood as a mix both of liberal and populist political ideas and of (vague) principles of participation (pp. 17-18). 
4 The surveys conducted of course go beyond and qualify these general points. First of all, four fifths of the people questioned (with the exception of Mongolia, where the figure is 70 percent) feel they are capable neither of understanding nor of participating in political affairs. However, more than two thirds of them describe as dictatorial the regime that preceded the one currently in power (for example, Japan before 1945, China before 1979, other countries before their democratisation), except for respondents in Hong Kong who, for reasons that are easy to understand, see a regression in the evolution after 1997. And logically, with the exception of Hong Kong again, the people surveyed regard the present political system as "relatively or very democratic," including the Chinese ( 84 percent), whose optimism results from the addition of freedoms and improvement in the standard of living after the death of Mao Zedong. It has to be added that nearly half of the respondents in China perceive only a "moderate evolution towards democracy" in the current situation (see below).

5 Probably more important, support for democracy in East Asia (except in Thailand) remains dependent on the political and economic performance of the government in place. This dependence exceeds not only that in southern Europe (Spain), but also in sub-Saharan Africa and even Latin America. Nevertheless, more than two thirds of the people surveyed reject any return to an authoritarian regime (strongman, one-party state, military dictatorship, and technocracy), including in China, although only the last two questions could be included in the survey there (military regime and "experts decide everything").

6 Another essential question is the relationship between democracy and the rule of law. In the six democracies and in Hong Kong, this relationship is generally close: those who think that their government should not overstep the law are very numerous (South Korea: 77 percent; Hong Kong: 70 percent; Taiwan: 58 percent; and in Thailand, where populist tendencies are more apparent, 49 percent; the question was not asked in China). The principle of judicial independence, on the other hand, is less soundly anchored: well accepted in South Korea (69 percent), Japan (62 percent), and to a lesser degree in Taiwan (54 percent), it is only upheld by a minority of Filipinos (39 percent), Thais (40 percent), and Chinese (31 percent). Similarly, parliament, often unpopular in East Asia, is only clearly regarded as a useful counter-power to the executive by South Koreans ( 54 percent) and Japanese (50 percent). Only 47 percent of Hong Kong citizens and Thais, 34 percent of Chinese, and 25 percent of Taiwanese think this is the case.

7 Finally, these societies are on the whole both optimistic and realistic about the future: the Chinese, Mongolians, and Thais more so than the South Koreans, Taiwanese, Hong Kongers, and Japanese. These trends result from the conclusions that each of these societies has drawn regarding its current regime, its political performance, and in particular its ability to combat corruption.

8 Overall, this work reveals how the problems faced by the political regimes of East Asia are shared by other regions of the world: the new democracies in Eastern Europe, Latin America, and Africa, but also, to a certain degree and for different reasons, Russia and India.

9 It is impossible, in this short review, to do justice to the richness of the data compiled and of the conclusions proposed. It is necessary, however, to mention some reservations on the method and some of its unintended consequences. First of all, this is a snapshot, a still photograph, of the state of political culture in six Asian societies that are certainly dependent on the global context (the third wave of democratisation, 
then its ebb), but that are also evolving according to specific national trajectories. The democratic confidence of the Thais or the optimism of the Chinese can only raise doubts in the reader's mind regarding the impact of these opinions on the regimes being studied. As the authors admit, other factors weigh more heavily: in Thailand, the weak inclination of the elite for democracy, in China, a political conditioning successfully implemented by the Communist Party.

Similarly, if the moment chosen is necessarily arbitrary, it has considerable influence on the responses received. Thus one can wonder about the degree of "nostalgia" among the Taiwanese for the authoritarian regime of the Chiang family. It is true that in 2001 the popularity of Chen Shui-bian was very low (although it experienced an even more dramatic drop after his disputed re-election in 2004). However, to write that "authoritarianism remains a formidable potential competitor to democracy" (p. 108) seems exaggerated: indeed, neither Taiwanese society nor above all its elite seriously envisage a reappraisal of the democratic consensus, all the less so in view of the challenge represented by the rising power of authoritarian mainland China.

When feasible, developments that occurred after the surveys were conducted have been included to qualify some seemingly incoherent results. But the authors can only be encouraged to repeat the surveys at regular intervals. That would provide a more dynamic and probably more accurate representation of the perceptions and trends examined.

12 I would like to finish with a thought on the case of China that I raised above. One can only salute the work carried out by Tianjian Shi, which is ground-breaking in many respects. But he leaves in a state of perplexity and pessimism all those who believe that the Chinese share the same political values as Westerners and as their closer neighbours and "compatriots." It is seen that 84 percent of some 3,183 people surveyed in China believe that their political regime is already democratic, and that 66 percent think this democracy will continue to deepen. In other words, the Chinese Communist Party has succeeded in imposing its own definition of democracy; the Chinese have almost total confidence in their institutions, in particularly the central institutions, whether it is the government, the National People's Congress, the Communist Party, the army, or the media (over 90 percent). And the least popular institutions (though still inspiring confidence in 58 percent and 62 percent of respondents) are exactly those that the Americans and Europeans are banking on - private enterprises and nongovernmental organisations - to promote the concept of democracy in China (p. 229). The only ray of optimism comes from the close and positive relationship Shi establishes between education level, age, and urbanisation, on the one hand, and an increase in the demand for democracy on the other. But for such optimism to prevail, the concept of democracy as it is almost universally understood would first have to dethrone the Chinese-communist conception of this ideal-type. And that will be no simple task, despite the Internet and all the rest...

In short, this book is essential reading.

Translated by Nick Oates 